\title{
SHASHI
}

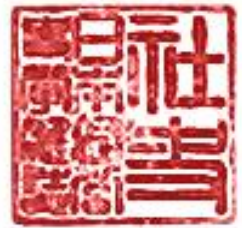

The Journal of Japanese Business and Company History

\section{From the Chair of the Shashi Group}

\author{
Hiroyuki N. Good \\ University of Pittsburgh
}

$\mathrm{W}$ e have collected more than 20,000 volumes of shashi, Japanese company histories as of December 2012. Ohio State University has about 5,000 titles; University of Hawai'i at Manoa and University of Pittsburgh have about 3,000 titles each. ${ }^{1}$ University of Chicago and Library of Congress have about 2,000 titles each. They are the top five. University of California, Berkeley has about 1,6000 titles, Harvard University has about 900 titles, Colombia University has about 800 titles, University of California, San Diego has about 750 titles, and Yale University has about 600 titles. ${ }^{2}$ The total of number of shashi titles in the above ten university libraries is about 19,650 titles. In addition to the top ten, University of Kansas, University of California, Los Angeles, University of Illinois at Urbana-Champaign and University Southern California are active members of the Shashi Cooperative Collection Development Project by the Japanese Company Histories (Shashi) Interest Group (Shashi Group, hereafter).

It is difficult to estimate how many mutually exclusive and collectively exhaustive titles of shashi are held in North America; however, as of December 2012, about 6,000 titles of shashi by 2,960 companies are registered in the the Shashi Wiki, a union catalog of shashi in North America, which is one of major projects of the Shashi Group. ${ }^{3}$ It is also difficult to estimate how many shashi are published in Japan since many of them are self-published and there is no official record. However, we can say that there are at least 15,000 titles of because this is the number of shashi in the collection held by the Kanagawa Prefectural Kawasaki Library, which is famous as the largest shashi collection. ${ }^{4}$ Therefore, it is a blessing and an astonishing fact that $40 \%$ of existing shashi are available for you in North America.

Acquisition of Shashi in North America started in 1980s. Shashi is a grey literature that is self-published by companies to commemorate their 10th, 50th and 100th anniversaries and it focuses on their founders and their own history. However, many researchers on Japan have recognized shashi as important resources because shashi contains not only history of its own company but also history of industries, technologies, advertisements, etc. It also contains hard-to-find primary resources owned by companies. This is the reason why Maureen Donovan, Japanese Studies librarian at the Ohio State University, purchased all shashi, 759 titles with 887 volumes, owned by a

${ }^{1}$ Numbers of titles for first three universities are based on interviews with Japanese Studies Librarians at each University.

${ }^{2}$ Numbers of titles for these seven universities are based on my search on OCLC WorldCat and universities' OPAC. Japanese Company Histories (Shashi) Interest Group, Shashi Wiki.

http://library.osu.edu/wikis/shashidb/index.php/Main Page. Last accessed Dec. 19, 2012. See below for more details.

${ }^{4}$ Kanagawa Prefectural Kawasaki Library, Riyō annai. http://www.klnet.pref.kanagawa.jp/kawasaki/guide/guide.htm.

Last accessed Dec. 19, 2012. 
secondhand bookstore at Kanda Jinbōchō when the University library received financial support for Japanese Studies from Japanese companies making inroads into markets on Ohio State in 1984. Since then, Maureen has made steady efforts by writing letters to ask Japanese companies to donate shashi and searching old and rare shashi at secondhand bookstores to build a largest shashi collection outside of Japan.

At the same time, Eizaburo Okuizumi, Japanese Studies librarian at the University of Chicago, also focused attention on importance of shashi. Although He did not have special budget, he has started to collect shashi especially edited by scholars, such as Kaō Sekken gojünenshi and Ötsuka Seika Kabushiki Kaisha gojūnen: shinise no kindaika. He has also collected shashi related materials, such as Mitsui Bussan jigyō hōkokusho (Business report of Mitsui \& Co., Ltd.) ${ }^{5}$, and Mitsui Bussan shitenchō kaigi gijiroku (Minutes of Mitsui \& Co., Ltd. branch managers meetings) ${ }^{6}$ with financial support by the Multi-Volume Sets Project of the North American Coordinating Council on Japanese Library Resources. ${ }^{7}$

Our chance of a breakthrough in development of shashi collection in North America came at the 2001 Annual Conference of Association of Asian Studies (AAS) in Chicago. Katsuko Murahashi, then Information Media Group Chief and librarian at the Keidanren and one of the leading shashi researchers, was invited as a guest speaker at a meeting of the Committee of Japanese Materials of the Council of East Asian Libraries. Izumi Koide, then librarian at the International House of Japan and current director of the Resource Center for the History of Entrepreneurship, the Shibusawa Eiichi Memorial Foundation, and Maureen Donovan of the Ohio State University were arranged the meeting. Murahashi gave a concise and impactful presentation. As some particular aspects of shashi, she stated that publishing companies of shashi were not limited to particular types of industries and such publication was not affected by economic situations, and that shashi was often re-written as time passes depending on the interpretation of what happened in the past, so it is important to read shashi of different editions. She also introduced us to academic, special and public libraries housing large collection of shashi, and secondhand bookstores dealing in shashi. ${ }^{8}$ Librarians and researchers had a meeting with Murahashi after the presentation and it developed annual business meetings of the Shashi Group at AAS. ${ }^{9}$

Tokiko Bazzell, Japanese Studies Librarian at the University of Hawai'i at Manoa, consulted Japanese Studies researchers at the university after she was inspired by Murahashi's presentation and began to collect shashi related to the local interest of Hawai'i, such as tourism, temples, real estate, etc. Tokiko has also made steady efforts by writing letters to ask Japanese companies to donate shashi and has built a second largest collection of shashi in North America.

The story of how the University of Pittsburgh has built a large collection of shashi matches well with an expression of tana kara botamochi, or windfall. Unexpected fortune came in 2004. The University of Pittsburgh received a donation of 64,000 volumes of books and journals from Kinyū Keizai Kenkyūjo, or the Research Institute of Financial Economy, of the former Mitsui Bank. Dr. Richard Smethurst, UCIS Research Professor of the University of Pittsburgh and an author of From Foot Soldier to Finance Minister: Takahashi Korekiyo, Japan's

${ }^{5}$ Mitsui bussan gomei gaisha, Mitsui Bussan Jigyō hōkokusho. 4 DVD-ROMs. Meiji 30-nen shimohanki [1897, second half] - Showa 19-nendo kamiki [1944, first half]. Tokyo: Maruzen, 2007.

${ }^{6}$ Mitsui bussan gomei gaisha, Mitsui bussan shitenchō kaigi gijiroku. 16 volumes Meiji 35 [1092]-Shōwa 6 [1931]. Tokyo: Maruzen, 2004.

${ }^{7}$ North American Coordinating Council on Japanese Library Resources. Multi-Volume Sets Project. http://guides.nccjapan.org/mvs. Last accessed Dec. 19, 2012.

${ }^{8}$ Katsuko Murahashi. Japanese company histories: characteristics and culture value. Journal of East Asian Libraries, Vol.124, no.1 (2001), 41-49. https://ojs.lib.byu.edu/spc/index.php/JEAL/article/view/8551/8200. Last accessed Dec. 19, 2012.

${ }^{9}$ Maureen Donovan. Japanese Company Histories Interest Group Meeting. Journal of East Asian Libraries, Vol.124, no.1 (2001), 50-53. https://ojs.lib.byu.edu/spc/index.php/JEAL/article/view/8552/8201. Last accessed Dec. 19, 2012. 
Keynes, ${ }^{10}$ received an inquiry from Professor of Norio Tamaki of the Keio University regarding the donation. Mitsui Bank was looking for an overseas institution that was willing to receive the entire collection of its financial research institute because the bank closed it in conjunction with major bank merger in $2001 .{ }^{11}$ A total of 2,276 volumes of shashi were included in the Mitsui Collection. Since then, I have also built the second largest collection of shashi in North America with 3,000 volumes by writing letters to ask Japanese companies to donate shashi and by setting up a donation project of duplicate shashi from Japanese institutions.

In order to promote usage of shashi as academic resources and further collection development, the Shashi Group conducts three major projects. First, as I mentioned above, we have developed a union catalog of shashi in North America, Shashi Wiki. It was established by Donovan on the website of The Ohio State University Library in June 2006. Each page is created for a company and participating university libraries register the shashi they hold. Each shashi has link to a record of the OCLC's WorldCat, so that users can access bibliography and holding library information for requesting interlibrary loan. Also, each university library can create a shashi collection list by adding tag to records. Users can browse shashi by alphabetical order and order of the Japanese syllabary of company name, by the Ryūkoku University Nagao Bunko catalog ${ }^{12}$, by Nikkei Business Classification ${ }^{13}$, and by List of shashi collections by university libraries in North America. There are seven university libraries participating in the Shashi Wiki Project; The Ohio State University, University of California, Los Angeles, University of California, San Diego, University of Illinois at Urbana-Champaign, University of Kansas, University of Pittsburgh, and Yale University.

Second, we have held business meetings and panel discussions at AAS annual conferences since 2001. There were only less than 20 participants at the first business meeting in 2001; however, more than 50 librarians and researchers attended at our business meeting in 2010. In 2005, we held our first panel discussion, "Treasure Troves for Research: Japanese Company Histories (Shashi)" in Chicago. ${ }^{14}$ In 2011, we held second panel discussion "Researching with Shashi: A Workshop on Using Japanese Company and Institutional Histories and Archives" in Hawai'i. ${ }^{15}$ In 2012, we held third panel discussion "Researching Early Modern and Modern History of Japan with Shashi" in Toronto. ${ }^{16}$ Please refer links included in the footnote for abstracts of presentations. Some of the presentations were re-written by authors and included in this inaugural issue.

Third, as I mentioned at the beginning, we have conducted Shashi Cooperative Collection Development Project. Each active library member of the project collects shashi based on local interest. For instance, University of Pittsburgh focuses on steel industry because Pittsburgh prospered as "the Steel City" and on financial industry because of the Mitsui Collection. We arranged donation project of duplicate shashi from two Japanese institutions. Six university libraries received 382 volumes of duplicate shashi from the Kanagawa Prefectural Kawasaki Library

${ }^{10}$ Richard Smethurst. From Foot Soldier to Finance Minister: Takahashi Korekiyo, Japan’s Keynes, Harvard University Asia Studies Center, 2007.

${ }^{11}$ Regarding the Mitsui Collection, please refer Eizaburo Okuizumi. The global era of the Mitsui Collection - reshaping Japanese rare book collection in North America. The Bulletin of the Publication Project for Japanese in North America. No. 19 (March, 2008). http://www.bunsei.co.jp/pdf/shiori019.pdf. Last accessed Dec. 19, 2012.

${ }^{12}$ Ryūkoku University. Nagao Bunko Web mokuroku, http://rwave.lib.ryukoku.ac.jp/opac/nagao/opac nagao.cgi. last accessed Dec.19, 2012.

${ }^{13}$ Nihon Keizai Shinbunsha. Nikkei heikin saiyō meigara no ichiran. http://www.nikkei.com/markets/kabu/nidxprice.aspx?index=N300. Last accessed Dec. 19, 2012.

${ }_{14}$ Tokiko Bazzell. Treasure Troves for Research. http://www.hawaii.edu/asiaref/japan/company/aas/aas_ad.htm. Last accessed Dec. 19, 2012.

${ }^{15}$ Hiroyuki Good. 2011 Workshop. http://library.osu.edu/wikis/shashidb/index.php/2011_Workshop. Last accessed Dec. 19, 2012.

${ }^{16}$ Hiroyuki Good. Researching Early Modern and Modern History of Japan with Shashi. http://www.asianstudies.org/absts/2012abst/abstract.asp?Session_ID=1237\&year=2012\&PanelArea_ID=2\&area=Japan\&Meeting_ID=2 1. Last accessed Dec. 19, 2012. 
and four university libraries received 44 volumes of duplicate shashi from the Shibusawa Eiichi Memorial Foundation this year.

At the 2013 AAS conference in San Diego, we will again have the panel discussion "The Shiseido Culture: Design, Fashion and Marketing" on Sunday, March 24, 2013, from 10:15 am to 12:15 pm, session number is 357 . Shiseido Cosmetics Company commemorated 140 years anniversary in 2012. The company has built originality that is worthy of being called 'Shiseido Culture' with its excellent business sense and design, becoming a worldrenowned brand. The company has continually cultivated the Shiseido Culture within and outside of the company and it makes contributions to society through design and marketing. The company has also considers the Shiseido Culture and its history to be an important management asset and has published more than 60 titles of shashi, or company history books, and publications related to design and advertisement since 1957. For researchers who study art history, cultural history and business history, these publications are very important primary resources. This panel has invited four researchers to discuss how Shiseido Culture has had effects on the history of design and advertisements in Japan, the relationship between imperial Japan and women's fashion, and Japanese marketing in colonies. Please join us. 


\section{(cc) $\mathrm{BY}$}

New articles in this journal are licensed under a Creative Commons Attribution 3.0 United States License.

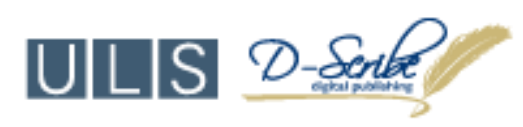

This journal is published by the University Library System, University of Pittsburgh as part of its D-Scribe Digital Publishing Program and is cosponsored by the University of Pittsburgh Press. 